\title{
Feeding ecology of the Neotropical otter Lontra longicaudis in the Lower Arroio Grande River, southern Brazil
}

\author{
KLEISSON S. SOUSA ${ }^{1}$, VINICIUS A.G. BASTAZINI ${ }^{2}$ and ELTON P. COLARES ${ }^{3}$ \\ ${ }^{1}$ Programa de Pós-Graduação em Biologia de Ambientes Aquáticos Continentais, \\ Universidade Federal do Rio Grande/FURG, Av. Itália, Km 8, Campus Carreiros, 96201-900 Rio Grande, RS, Brasil \\ ${ }^{2}$ Programa de Pós-Graduação em Ecologia, Laboratório de Ecologia Quantitativa, \\ Universidade Federal do Rio Grande do Sul/UFRGS, Av. Bento Gonçalves, 9500, 91501-970 Porto Alegre, RS, Brasil \\ ${ }^{3}$ Instituto de Biologia, Universidade Federal do Rio Grande/FURG, \\ Av. Itália, Km 8, Campus Carreiros, 96201-900 Rio Grande, RS, Brasil
}

Manuscript received on December 20, 2010; accepted for publication on June 29, 2012

\begin{abstract}
The present study was based on the analysis of spraints $(n=294)$ collected between December 2005 and November 2007. The importance of each type of prey was determined by absolute and relative frequency. Niche breadth was also estimated. The results were reported as mean $( \pm \mathrm{SD})$ of relative frequencies. Fish were the main prey found in spraints $(57.8 \pm 7.0 \%)$. Fish from Callichthyidae family were the main prey, followed by Cichlidae, the species Hoplias malabaricus and the family Characidae. The frequencies of other fish and taxa were lower than $13.9 \%$ (absolute frequency) and 5.6\% (relative frequency). Despite significant seasonal variations, $(\mathrm{P}=0.001)$, niche breadth values were low in all seasons $(0.39 \pm 0.11)$. Therefore, Lontra longicaudis presented a narrow niche breadth as a result of consistent fish predation. Based on these data, fish with rapid movement presenting territorial behavior and benthic fish with slow movements are the most consumed. Seasonal fluctuations are caused by the increase of secondary prey in the diet during some seasons.
\end{abstract}

Key words: diet, neotropical otter, niche breadth, seazonal, southern Brazil.

\section{INTRODUCTION}

There are 13 currently recognized otter species in the world (Kruuk 2006). All of them have morphological and physiological adaptations to aquatic environments (Estes 1989). The Neotropical otter Lontra longicaudis (Mustelidae: Lutrinae) has a wide geographical distribution; it occurs from northern Mexico to Argentina and Uruguay, including most of the Neotropical region, except for Chile (Larivière 1999). Its distribution includes areas of different climates and habitats:

Correspondence to: Kleisson da Silva de Sousa

E-mail: kscarnivoros@hotmail.com rivers, lakes, ponds, salt marshes, rocky seashores, marshlands and mangroves, what evidences the species' high ecological tolerance (Kruuk 2006).

Despite its large distribution in Latin America, L. longicaudis has been poorly studied and is considered as a 'virtually unknown' carnivore (Mason and Macdonald 1986, Kruuk 1995, 2006). Most of the published information about this species is related to its feeding habits; most studies have been carried out in Brazil, mainly in the southern region. Studies in southern Brazil have covered different aquatic environments, such as the estuarine region and lagoon of Florianópolis 
(Alarcon and Simões-Lopes 2004, Carvalho-Junior et al. 2010a, b), rivers from northern Santa Catarina State (Quadros and Monteiro-Filho 2001), rivers from central Rio Grande do Sul State (Kasper et al. 2004a, b, 2008), and coastal lakes and streams from far south Rio Grande do Sul State (Colares and Waldemarin 2000). Further information about L. longicaudis in Brazil comes from Paranoá Lake in central Brazil (Louzada-Silva et al. 2003), Duas Bocas Biological Reserve in Espírito Santo State (Helder and Andrade 1997), and Betari River in São Paulo State (Pardini 1998). Most authors reported that the species feeds mainly on fish, though it may also include other vertebrates and some invertebrates in its diet. In general, authors have not taken into account functional and ethological characteristics of its prey. Nonetheless, some studies have suggested that territorial fish, benthic fish and crustaceans are among its most frequent prey (Helder and Andrade 1997, Pardini 1998, Quadros and Monteiro-Filho 2001, Kasper et al. 2008).

Data on seasonal variation in the diet of $L$. longicaudis are scarce (e.g. Helder and Andrade 1997, Pardini 1998, Colares and Waldemarin 2000, Quadros and Monteiro-Filho 2001, Kasper et al. 2008, Carvalho-Junior et al. 2010a, b). Only a few authors carried out long-term studies (Carvalho-Junior et al. 2010a, b). The temporal information available to far southern Brazil is anecdotal and lacks formal quantitative analysis (Colares and Waldemarin 2000).

Feeding is a key aspect of animal ecology, as it involves many important biological characteristics (Crawshaw-Junior 1997). Therefore, knowing the feeding habit of a species is a fundamental tool for developing effective conservation programs and biomonitoring studies (Korschgen 1987).

Currently, L. longicaudis is listed worldwide as 'data deficient' (IUCN 2010), and it is considered as endangered (CITES 2011) in the categories 'near threatened' in Brazil (Chiarello et al. 2008) and 'vulnerable' in the state of Rio Grande do Sul (Indrusiak and Eizirik 2003).
According to Indrusiak and Eizirik (2003), investigations on the species' bio-ecological features are recommended for the elaboration of its conservation plans.

The present study aims at characterizing the feeding spectrum, seasonal variation and niche breadth of $L$. longicaudis in the Lower Arroio Grande River, southern Brazil. Our main aim is to understand how dietary composition oscillates as a result of the marked climatic seasonality (seasons) of southern Brazil.

\section{MATERIALS AND METHODS}

STUDY AREA

Our study took place in the Lower Arroio Grande River ( $\left.32^{\circ} 18^{\prime} \mathrm{S}, 52^{\circ} 56^{\prime} \mathrm{W}\right)$, located in the Piratini-São Gonçalo-Mangueira Watershed, state of Rio Grande do Sul, southern Brazil. The study site is located in the inner coastal plain in the unit classified as alluvialcolluvial, between the Sul-Rio-Grandense Plateau (west) and the Lagunar Plain (east) (Justus et al. 1986). The Arroio Grande River originates in the south of the Sul-Rio-Grandense Plateau and flows into the Mirim Lake. The lower course flows through an agro-pastoral landscape, with predominance of rural grasslands composed of dry and wet fields, followed by the riparian forest of Arroio Grande River. The riparian forest is characterized, according to Waechter (1985), as sandbank vegetation, composed of sandy forests that grow at low elevations on peats or frequently flooded, poorly drained soils. Additionally, rice growing stands out as the main economic activity, which established a network of artificial canals built for irrigation.

\section{DATA COLLECTION AND ANALYSIS}

The methodology used to study the feeding ecology of L. longicaudis was based on scat analysis (Korschgen 1987). This method is unanimously used in studies on the feeding ecology of the Neotropical otter. However, this method has some major disadvantages. As shown by Carss and Parkinson 
(1996), the contents found in spraints do not reflect the diet accurately, but provide a rough estimate (Carss and Parkinson 1996, Kruuk 2006). Nonetheless, this nonintrusive method allows the accumulation of much information in a relatively quick and inexpensive way (Korschgen 1987, Crawshaw-Junior 1997) and can be easily replicated across time and space.

From December 2005 to November 2007, we took 2-3 field trips per season to collect spraints along a 5-km section in the alluvial plain of Arroio Grande River. The length of trails varied throughout the year, following Arroio Grande's flood pulse, as many sampling sites became inaccessible during winter floods. We divided the data according to season: summer (from December to February 2006, $\mathrm{n}=12 ; 2007, \mathrm{n}=17$ ), autumn (from March to May $2006, \mathrm{n}=46 ; 2007, \mathrm{n}=31$ ), winter (from June to August 2006, $\mathrm{n}=51 ; 2007, \mathrm{n}=43$ ) and spring (from September to November 2006, $\mathrm{n}=14 ; 2007, \mathrm{n}=$ 80). We collected and analyzed 294 otter spraints, which were identified through odor and shape. In the laboratory, every scat was washed in a fine-mesh sieve $(0.5-1 \mathrm{~mm})$ under running water, in order to remove all soluble material. Undigested parts and hard structures were used to identify prey items. Fish were identified, with the help of specialists, based on structures such as scales (C.F. Josef, unpublished data), vertebrae, mouth parts, otoliths, skull bones, fin rays and bone plates. Fish identification was done only through structures that allowed recognizing prey items. We assumed that unidentifiable undigested remains and bone fragments belonged to one of the prey items already identified in the scat. Mammals were identified through hairs, claws and teeth (incisors and third molars), which were compared to a reference collection from our study site. Birds were identified following the procedures proposed by Day (1966), through bill and tarsus remains. Amphibians were identified through bones, snakes through scales, insects through exoskeleton and wings, molluses through operculum, and crustaceans through carapace.
We calculated absolute and relative frequencies from a binary matrix (presence and absence) (Durigan 2003). The absolute frequency (AF) represents how common an item is in the diet.

$$
A F i=\frac{100 \mathrm{p}}{\mathrm{P}}
$$

Where $A F i$ is the absolute frequency of a given prey $(\%), p$ is the number of spraints with parts of a given prey, and $\mathrm{P}$ is the number of spraints analyzed.

The relative frequency $(R F)$ represents the importance of a dietary item from 0 to $100 \%$.

$$
R F i=\frac{100 A F i}{\sum_{i}^{n}=A F i}
$$

Where $R F i$ is the relative frequency of a prey $i$ $(\%), A F i$ is the absolute frequency of a prey $i(\%)$.

Niche breadth was estimated using the Levins index (B) (1968).

$$
B=\frac{1}{\sum p_{j}^{2}}
$$

Where $p_{\mathrm{j}}$ represents the relative frequency individuals in the $\mathrm{j}^{\text {th }}$ category. In order to calculate this index, prey items were organized in the following categories: insect, mollusc, fish, amphibian, reptile, bird and mammal. Levins' niche breadth was standardized $\left(B_{\text {sta }}\right)$ following Colwell and Futuyma (1971).

$$
B_{\text {sta }}=\frac{B-1}{B_{\max }-1}
$$

Where $B_{\max }$ is the total number of categories found. The result ranges from 0 to 1 . A value close to 1 indicates a broad trophic niche without the predominance of any prey in the diet, whereas values close to 0 indicate a narrow trophic niche, with the predominance of one or a few prey (Krebs 1999).

A multivariate analysis was used to test for temporal variations. A correspondence analysis was used to assess the relationship between seasons (objects) and the consumption rates of different prey categories (variables) (Legendre and Legendre 
1998). Prior to the analysis, data were transformed to deviations from expected values based on marginal totals. Pearson's product moment was used as resemblance measure.

To explore the temporal variation in the diet of L. longicaudis, permutational multivariate analysis of variance using the sum of squares $(\mathrm{Qb}$ statistic) between groups and within groups as our test criteria, following Pillar and Orlóci (1996). The resemblance matrix was generated based on Euclidean distances and p-values; we used 1,000 iterations. The significance level used in all analysis was $\alpha=0.05$. All multivariate analyses were made in the package MULTIV 2.4 (Pillar 2006).

\section{RESULTS}

\section{FOOD COMPOSITION}

The average ( \pm SD) relative frequency per season shows that fish was the most frequently consumed item, representing $57.8 \pm 7.0 \%$ of all prey items; it was followed by rodents with $20.1 \pm 13.0 \%$. The remaining taxa had values below $8.7 \%$ (Figure 1).
Fish of the family Callichthyidae were the most frequent prey of $L$. longicaudis, considering both $A F$ and $R F$, followed by the family Cichlidae, the species Hoplias malabaricus and the family Characidae. The remaining items were present in less than $13.9 \%(A F)$ of the spraints, and exhibited values below $5.6 \%$ (Table I).

\section{Seasonal Variation of Feeding Spectrum and Niche} BREADTH

Considering $R F$ values, fish were the main prey in all periods, throughout the two years of investigation, always exhibiting values over $50.6 \%$. The highest relative frequencies were observed in the winter of $2007(70.7 \%)$ and in the spring of 2007 (63.6\%). Those periods were marked by strikingly low values of niche breadth. Rodents were present in all seasons, except for the summer of 2006. Rodents reached the highest values in the winter (40.5\%) and spring of 2006 $(35.0 \%)$. Birds were consumed in six of the 8 seasons studied. In the autumn of 2006, birds were

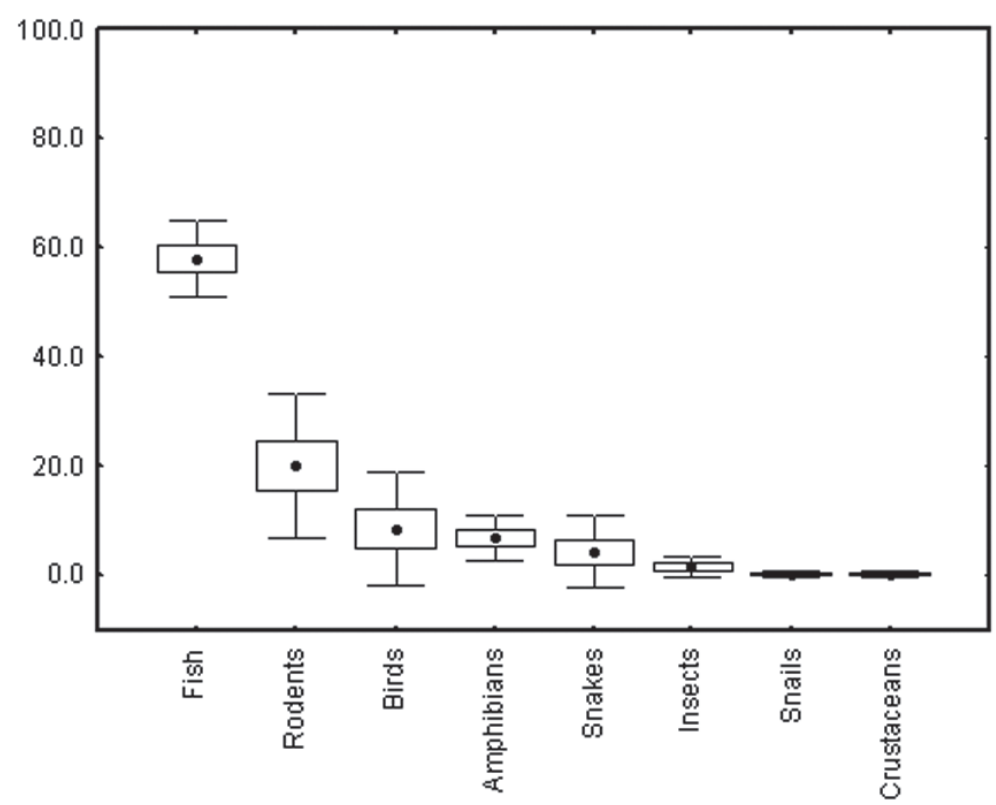

Figure 1 - Average relative frequency (circle inside the box), standard error (box), and standard deviation (whiskers) of food items found in the spraints of L. longicaudis in the Lower Arroio Grande River between December 2005 and November 2007. 
TABLE I

Feeding items found in the spraints of $L$. longicaudis in the Lower Arroio Grande River, between December 2005 and November 2007. Absolute frequency $(A F)$ and relative frequency $(R F)$.

\begin{tabular}{|c|c|c|c|}
\hline Taxon & & $A F$ & $R F$ \\
\hline \multirow{20}{*}{ FISH } & Siluriformes & & \\
\hline & Callichthyidae & 45.5 & 18.5 \\
\hline & Heptapteridae & & \\
\hline & Rhamdia quelen & 7.8 & 3.2 \\
\hline & Pimelodidae & & \\
\hline & Pimelodella australis & 3.1 & 1.2 \\
\hline & Auchenipteridae & & \\
\hline & Trachelyopterus lucenai & 4.8 & 1.9 \\
\hline & Perciformes & & \\
\hline & Cichlidae & 43.5 & 17.6 \\
\hline & Characiformes & & \\
\hline & Characidae & 19.4 & 7.8 \\
\hline & Erytrinidae & & \\
\hline & Hoplias malabaricus & 28.2 & 11.1 \\
\hline & Curimatidae & 4.1 & 1.6 \\
\hline & Cyphocharax voga & 13.9 & 5.6 \\
\hline & Synbranchiformes & & \\
\hline & Synbranchidae & & \\
\hline & Synbranchus marmoratus & 8.2 & 3.3 \\
\hline & Undertermine Fish & 6.1 & 2.5 \\
\hline \multirow{9}{*}{ MAMMALS } & Rodentia & & \\
\hline & Cricetidae & & \\
\hline & Holochilus brasiliensis & 10.2 & 4.1 \\
\hline & Oligoryzomys spp. & 2.4 & 1.0 \\
\hline & Caviidae & & \\
\hline & Cavia spp. & 5.4 & 2.2 \\
\hline & Myocastoridae & & \\
\hline & Myocastor coypus & 1.0 & 0.4 \\
\hline & Undertermined rodent & 12.9 & 5.2 \\
\hline \multirow{6}{*}{ BIRDS } & Passariformes & 0.3 & 0.1 \\
\hline & Anseriformes & & \\
\hline & Anatidae & 6.8 & 2.7 \\
\hline & Gruiformes & & \\
\hline & Rallidae & 2.0 & 0.8 \\
\hline & Undertermined bird & 2.0 & 0.8 \\
\hline \multirow{5}{*}{$\begin{array}{l}\text { AMPHIBIANS } \\
\text { REPTILES }\end{array}$} & Anura & 9.9 & 4.0 \\
\hline & Squamata & & \\
\hline & Colubridae & & \\
\hline & Helicops infrateniatus & 0.7 & 0.3 \\
\hline & Undertermined sanke & 4.8 & 1.9 \\
\hline \multirow{3}{*}{ INSECTS } & Coleoptera & 0.3 & 0.1 \\
\hline & Hemiptera & & \\
\hline & Belostomatidae & 2.4 & 1.0 \\
\hline CRUSTACEANS & Decapoda & 0.7 & 0.3 \\
\hline \multirow{3}{*}{ MOLLUSCS } & Gastropoda & & \\
\hline & Ampullariidae & & \\
\hline & Pomacea spp. & 0.3 & 0.1 \\
\hline TOTAL & & 248.0 & 100. \\
\hline
\end{tabular}

the second most important group in the diet of $L$. longicaudis $(R F=29.7 \%)$. Snakes were present in half of the seasons studied. In the summer of 2006, snakes were the second most frequently consumed prey $(R F=18.8 \%)$. In the other seasons, their frequencies did not exceed $8.5 \%$ (spring of 2007). Amphibians occurred in all seasons, except for the spring of 2006, though their relative frequencies were low, never exceeding $12.5 \%$. Invertebrates occurred in low percentages; mollusks occurred only in the winter of 2007 and crustaceans only in the spring of the same year (Figure 2).

The correspondence analysis showed the distribution of different prey items along a seasonal gradient (Figure 3). The first axis explained $41.08 \%$ of the total variance in the dataset, while the second axis explained $36.43 \%$ of the variance. The winter of 2006 and spring, which were seasons marked by a high frequency of rodents in the diet, were located at the negative end of the first axis. The winter of 2007, season in which fish were the most important prey, were plotted in the positive panel, along with the first axis. The autumn of 2006, which was marked by an increase in bird consumption, was plotted at the negative end of the second axis, whereas the summer of 2006 was plotted at the opposite end of the same axis, since this season was marked by the consumption of snakes. Seasons that had intermediate values of birds and rodents consumption (summer, autumn and spring of 2007) along with rarely consumed categories (crustaceans and mollusks) or categories that are consumed in small frequencies all-year-round (amphibians and insects) were located near the origin (Figure 3).

The randomization test indicated a temporal variation in the diet of $L$. longicaudis in the Lower Arroio Grande River ( $\mathrm{P}=0.001$, between groups). There was a significant variation in diet in 2006 except for the period spring-winter, and in 2007, except for the periods summer-autumn and spring-winter. The variations were also observed among seasons of 2005 and 2007; except for the summer periods. 


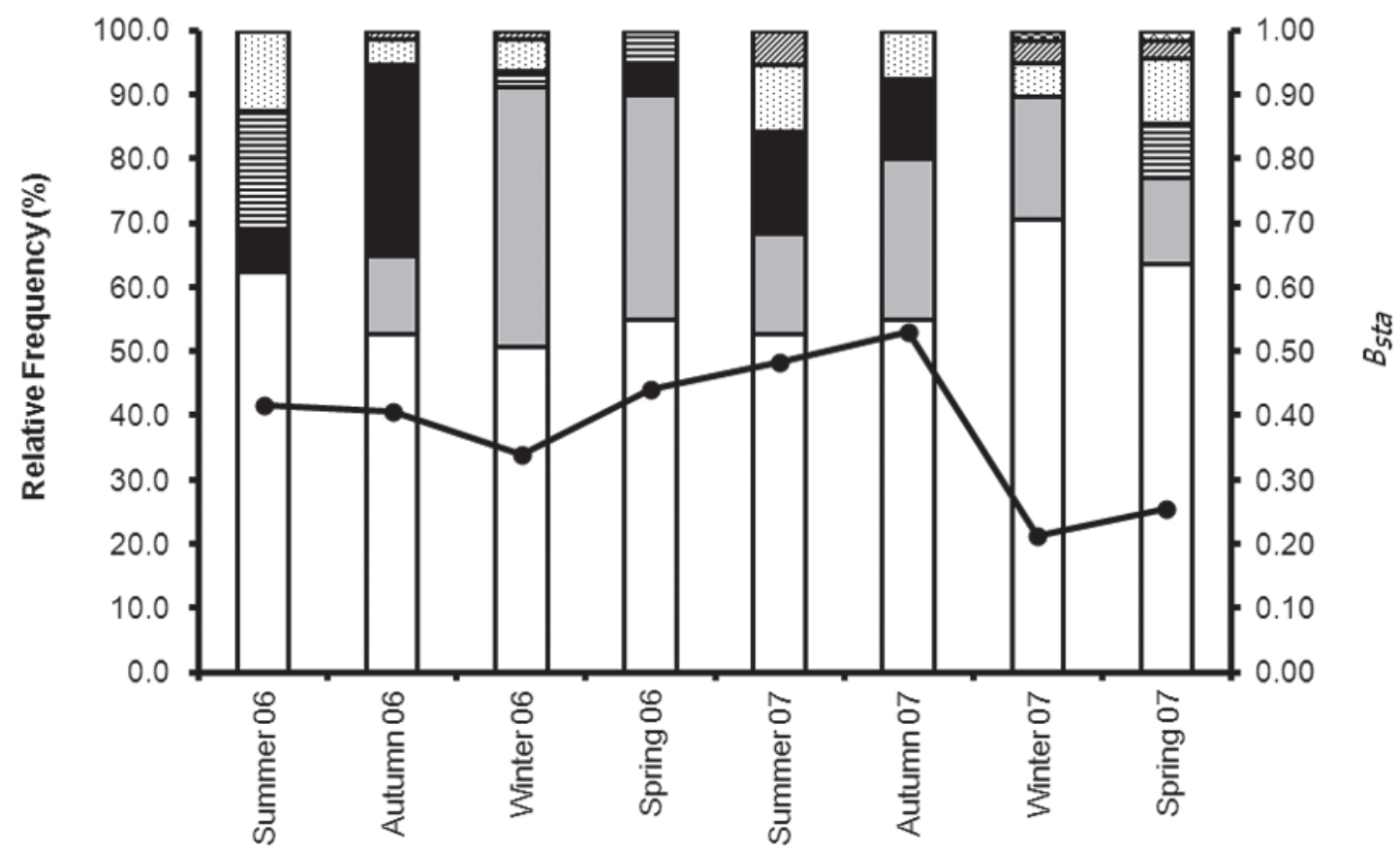

$\varpi$ Crustaceans $\infty$ Snails malnsects $\square$ Amphibians $\boxminus$ Snakes $\square$ Birds $\square$ Rodents $\square$ Fish $\rightarrow B_{\text {sta }}$

Figure 2 - Seasonal relative frequency of prey items found in the spraints of L. longicaudis, in the Lower Arroio Grande River, between December 2005 and November 2007. Line: values of the standardized trophic niche breadth index (Bsta), based on the same prey categories.

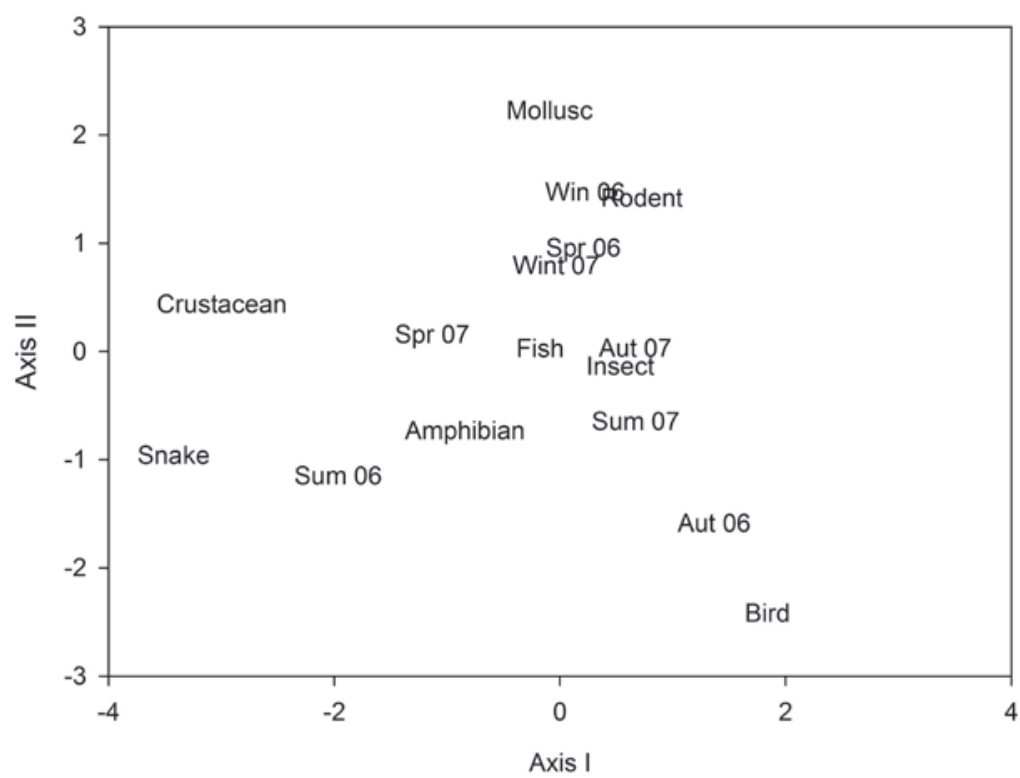

Figure 3 - Correspondence analysis showing the relationship between seasons and prey categories found in the spraints of L. longicaudis in the Lower Arroio Grande River. The data were collected between December 2005 and November 2007. Season names are abbreviated and followed by the respective year. Spr: spring; Sum: summer; Aut: autumn; Win: winter. The first axis explained $41.08 \%$ of the variance, whereas the second axis explained $36.43 \%$ of the variance. 
TABLE II

P-values from a Permutational Multivariate Analysis of Variance based on Euclidean distances, comparing the diet of $L$. longicaudis in different seasons, in the Lower Arroio Grande River.

\begin{tabular}{|c|c|c|c|c|c|c|c|c|}
\hline \multirow{2}{*}{$\begin{array}{l}\text { Between } \\
\text { groups } 0.001\end{array}$} & \multicolumn{4}{|c|}{2006} & \multicolumn{4}{|c|}{2007} \\
\hline & Summer & Autumn & Winter & Spring & Summer & Autumn & Winter & Spring \\
\hline \multicolumn{9}{|l|}{ Summer 06} \\
\hline Autumn 06 & 0.007 & & & & & & & \\
\hline Winter 06 & 0.000 & 0.001 & & & & & & \\
\hline Spring 06 & 0.009 & 0.008 & 0.640 & & & & & \\
\hline Summer 07 & 0.126 & 0.027 & 0.001 & 0.096 & & & & \\
\hline Autumn 07 & 0.041 & 0.008 & 0.007 & 0.420 & 0.578 & & & \\
\hline Winter 07 & 0.010 & 0.001 & 0.002 & 0.058 & 0.009 & 0.021 & & \\
\hline Spring 07 & 0.175 & 0.001 & 0.001 & 0.014 & 0.004 & 0.002 & 0.159 & \\
\hline
\end{tabular}

\section{DISCUSSION}

\section{FOOD COMPOSITION}

Our results show that fish are the main prey of $L$. longicaudis in the Lower Arroio Grande River, and that secondary prey change their importance throughout the seasons. Otters have evolved two distinct foraging models: fish-eating (piscivory seems to be the primitive foraging mode in otters) and invertebrate-eating (Estes 1989). Nonetheless, few species have followed exclusively one of those models (Estes 1989). Almost all otters are piscivorous, with the exception of the sea otter (Enhydra lutra) and species of the genus Aonyx (Mason and MacDonald 1986, Estes 1989, Kruuk 2006). Among the fish of Arroio Grande, less mobile benthic species, which bony plates (Callichthyidae) are more common; they are followed by more agile species, that are territorial fish, such as the Cichlidae and Hoplias malabaricus. This feature of the prey was also observed by Kasper et al. (2004a, b, 2008). However, the main prey of otters belongs to the family Loricariidae (less mobile and benthic). Pardini (1998) and Chemes et al. (2010) corroborated the Loricarriidae as the main prey of otters. Several otter species have been observed preying on fish that are slow and bottom-living, rather than on fast and pelagic fish (Kruuk 2006). However, this pattern is not consistent due to the wide variety of environments where L. longicaudis dwells. The otter's preference for the Cichlidae was reported by Helder and Andrade (1997), Quadros and Monteiro-Filho (2001) and Carvalho et al. (2010a). Those differences can be attributed to the aquatic environments where $L$. longicaudis occurs and to environmental conditions; some fish groups have morphological adaptations for living better in particular types of environments than in others (Breda et al. 2005).

Most studies have shown that crustaceans are usually the second most frequent item consumed by otters (Parera 1993, Helder and Andrade 1997, Macías-Sánchez and Aranda 1999, Colares and Waldemarin 2000, Gori et al. 2003, Alarcon and Simões-Lopes 2004, Carvalho-Junior et al. 2010a, b, Chemes et al. 2010). Nonetheless, in other sites, crustaceans are consumed at remarkably high frequencies (Spínola and Vaughan 1995, Pardini 1998, Quadros and Monteiro-Filho 2001). The low consumption of crustaceans observed in the Lower Arroio Grande River corroborates the results by Louzada-Silva et al. (2003), Kasper et al. (2004a, 2008). Most likely, differences observed in the diet of $L$. longicaudis in different regions result from local ecological peculiarities.

Rodents, birds, snakes and insects found in the diet of L. longicaudis belong to families or species of semi-aquatic habits. Other authors have 
also reported the predation of species with aquatic habits of those taxonomic groups (Pardini 1998, Macías-Sánchez and Aranda 1999, Quadros and Monteiro-Filho 2001, Gallo-Reynoso et al. 2008).

SEASONAL VARIation of FEEding Spectrum AND Niche BREADTH

In the Lower Arroio Grande River, the estimated niche breadth was quite narrow, despite some seasonal variations. Niche breadth variations in otters (measured by Shannon-Wiener index) were also reported by Macías-Sánchez and Aranda (1999) in the tropics. Many authors reported narrow niche breadths for $L$. longicaudis in tropical (Monroy-Vilchis and Mundo 2009) and subtropical areas (Kasper et al. 2008, Bastazini et al. 2009), except for Chemes et al. (2010). Thus, there are no reports of broad niche breadth (e.g. $B_{\text {sta }}>0.80$ ) for the species. Most published records show a general pattern, in which a few prey items, especially fish, are consumed at high frequencies, whereas other prey items are only occasionally eaten.

In the Lower Arroio Grande River we observed an increase in secondary prey (rodents, birds and serpents) in some periods. Some authors reported that a decrease in fish consumption may result in an increase in crustacean consumption (MacíasSánchez and Aranda 1999, Gori et al. 2003, Carvalho-Junior et al. 2010a, b). The variation observed in the ordination analysis reflects significant seasonal variations in the diet. Studies on temporal dynamics in the diet of the Eurasian otter (Lutra lutra) reported strong evidence of seasonal variation in freshwater environments (Kruuk 2006). The same pattern was observed for L. longicaudis in tropical (Macías-Sánchez and Aranda 1999, Pardini 1998) and subtropical areas (CarvalhoJunior et al. 2010b). Helder and Andrade (1997) observed variations between rainy and dry seasons, but did not find significant variations among seasons of different years (summer, autumn, winter and spring). Carvalho-Junior et al. (2010a), who studied otter diet in the subtropical region, did not find intra or inter-annual variations. Those differences may be attributed to the marked temporal changes of some aquatic environments and also to features of different ecosystems. In the Lower Arroio Grande River the water level increases in the winter due to high rainfall and low evapotranspiration. However, the summer is characterized by low rainfall and high evapotranspiration, which add up to water loss for the maintenance of irrigated rice fields close to the Lower Arroio Grande River, resulting in low water levels. It is possible that these seasonal changes in water level have a strong influence on the consumption of secondary prey, which causes high seasonal variations in the diet of $L$. longicaudis in the Lower Arroio Grande River.

In conclusion, the diet of L. longicaudis in southern Brazil is based on fish and its niche breadth is narrow. The Neotropical otter seems to prey upon the most vulnerable animals (e.g. territorial, fast-moving fish and slow moving, bottomdwelling fish). There are seasonal variations in diet composition. Probably, this is a consequence of their feeding flexibility combined with abrupt environmental changes between extreme seasons (winter and summer).

\section{ACKNOWLEDGMENTS}

The authors thank the Instituto de Ciências Biológicas (ICB) of Universidade Federal do Rio Grande (FURG), for the resources used in execution of this work. We are very thankful to the ecologist and veterinarian José B.G. Soares and his family for their warm welcome and gentleness. We are also thankful to Luis E.K. Lanes and Matheus V. Volcan for their assistance with fish identification and their comments on fish ecology, Daniel D. Saraiva and Elisa V. Salengue for their discussion on ecology and data analysis, Fábio A. Dutra, Marcelo D.M. Burns, Eduardo R. Sechi and Rafael A. Dias for 
revising the manuscript and for their comments. We are especially thankful to Hans Kruuk for revising the final version of this manuscript and for providing valuable comments and improvements.

\section{RESUMO}

O presente estudo foi baseado na análise das fezes ( $\mathrm{n}=$ 294), coletadas entre dezembro de 2005 e novembro de 2007. A importância de cada tipo de presa foi determinada pela frequência absoluta e relativa. A amplitude de nicho também foi estimada. Os resultados foram reportados como média $( \pm \mathrm{DP})$ da frequência relativa. Peixes foram a principal presa encontrada nas fezes $(57,8 \pm 7,0 \%)$. Peixes da família Callichthyidae foram a principal presa, seguido por Cichlidae, e espécies Hoplias malabaricus e Characidae. A frequência de outros peixes e a taxa foram menores do que 13,9\% (frequência absoluta) e 5,6\% (frequência relativa). Apesar das variações sasonais significativas, $(\mathrm{P}=0,001)$ os valores de amplitude de nicho foram baixos em todas as estações baixos $(0,39$ \pm 0,11). Portanto, Lontra longicaudis apresentou uma amplitude de nicho estreita, como resultado de uma predação consistente em peixes. Baseado nestes dados, peixe com movimento rápido apresentando o comportamento territorial e peixes bentônicos de pouco movimento são os maisconsumidos. Flutuações sazonais são causadas pelo incremento de presas secundárias na dieta durante algumas estações.

Palavras-chave: dieta, lontra neotropical, amplitude de nicho, sazonalidade, sul do Brasil.

\section{REFERENCES}

AlarCon GG AND SimÕES-Lopes PC. 2004. The Neotropical otter Lontra longicaudis feeding habitats in a marine coastal area, southern Brazil. IUCN Otter Spec Group Bull 21: 124-130.

BASTAZINI VAG, SoUSA KS AND DiAS RA. 2009. On the niche breadth of the Lontra longicaudis (Olfers, 1918) (Mustelidae: Lutrinae). In: CONGRESSO DE ECOLOGIA DO BRASIL, IX, Anais do Congresso de Ecologia do Brasil, Minas Gerais, Brazil.

BREDA L, OLIVEIRA EF AND GOULART E. 2005. Ecomorfologia de locomoção de peixes com enfoque para espécies neotropicais. Acta Sci Biol Sci 27: 371-381.
CARSS DN AND PARKINSON SG. 1996. Erros associated with otter Lutra lutra faecal analysis. I Assessing general diet from spraints. J Zool (Lond) 238: 301-317.

Carvalho-Junior O, Birolo AB And Macedo-Soares LCP. 2010a. Ecological aspects of neotropical otter (Lontra longicaudis) in Peri lagoon, south Brazil. IUCN Otter Spec Group Bull 27: 105-115.

CARVAlHo-Junior O, MACEDO-SOARES LCP AND BIROLO AB. 2010b. Annual and interannual food habits variability of a neotropical otter (Lontra Longicaudis) population in Conceição lagoon, south of Brazil. IUCN Otter Spec Group Bull 27: 24-32.

Chemes SB, Giraudu AJ And Gil G. 2010. Dieta de Lontra longicaudis (Carnivora: Mustelidae) em El Parque nacional El Rey (Salta, Argentina) y su comparación con otras e comparaciones con outras poblaciones de la cuenca del Paraná. Mastozool Neotrop 17: 19-30.

Chiarello AG, Aguiar lMS, Cerqueira R and Melo FR. 2008. Mamíferos Ameaçados de Extinção no Brasil. In: MACHADO ABN ET AL. (Eds), Livro vermelho da fauna Brasileira ameaçada de extinção Vol II, Brasília and Belo Horizonte: Ministério do Meio Ambiente and Fundação Biodiversistas, Brasília and Belo Horizonte, Brasil, p. 680-882.

CITES. 2011. Convention on International Trade in Endangered Species of Wild Fauna and Flora. < www.cites.org > Downloaded on 19 August 2011.

Colares EP AND WALdEMARIN HF. 2000. Feeding of the neotropical river otter (Lontra longicaudis) in the costal region of the Rio Grande do Sul State, Southern Brazil. IUCN Otter Spec Group Bull 17: 6-13.

COLWELl RK AND FUTUYMA DJ. 1971. On the measurement of niche breadth and overlap. Ecology 52: 567-576.

CRAWSHAW-JUNIOR PG. 1997. Recomendações para pesquisa sobre felídeos neotropicais. In: VALLADARES-PADUA C ET AL. (Eds), Manejo e conservação de vida silvestre no Brasil, Brasília and Belém: Sociedade Civil Mamirauá, Brasília and Belém, Brasil, p. 70-94.

DAY MG. 1966. Identification of hair and feather remains in the gut and faeces of stoats and weasels. J Zool (Lond) 148: 201-217.

DURIGAN G. 2003. Métodos para análise de vegetação arbórea. In: CULLEN-JUNIOR L ET AL. (Eds), Métodos de estudos em Biologia da Conservação \& Manejo da Vida Silvestre, Curitiba: UFPR, Curitiba, Brasil, p. 455-480.

ESTES JA. 1989. Adaptation for aquatic living by carnivores. In: GITTLEMAN JL. (Eds), Carnivore behavior ecology and evolution, New York: Cornell University Press, New York, USA, p. 242-282.

GALlO-REYNOSO JPG, RAMOS-RosAS NN AND RANGELAguilar O. 2008. Depredacíon de aves acuáticas por la nutria neotropical (Lontra longicaudis annectens), em el rio Yaqui, Sonora, Mexico. Rev Mex Biodivers 79: 275-279.

GORI M, CARPANETO GM AND OTTINO P. 2003. Spatial distribution and diet of the neotropical otter Lontra longicaudis in the Ibera Lake (northern Argentina). Acta Theriol 48: 495-504. 
HELDER J AND ANDRADE HK. 1997. Food habitats of the neotropical river otter Lontra longicaudis (Carnivora: Mustelidae). Mammalia 61: 193-203.

INDRUSIAK C AND EIZIRIK E. 2003. Carnívoros. In: FONTANA CS ET AL. (Eds), Livro vermelho da fauna ameaçada de extinção do Rio Grande do Sul, Porto Alegre: EDIPUCRS, Porto Alegre, Brasil, p. 507-534.

IUCN. 2010. IUCN Red List of Threatened Species. Version 2010.4. <www.iucnredlist.org>. Downloaded on 17 December 2010.

Justus JO, MACHADO MLA AND FRANCO MSM. 1986. Geomorfologia: Vol XXXIII. Folha SH. 22 Porto Alegre e parte das folhas SH 21 Uruguaiana e SI.22 Lagoa Mirim. In: IBGE Fundação Instituto Brasileiro de Geografia e Estatística (Eds), Levantamento de recursos naturais, Rio de Janeiro: IBGE, Rio de Janeiro, Brasil, p. 313-387.

Kasper CB, BASTAZINI VAG, Feldns MJ, SALVI J AND GRILHO HCZ. 2008. Trophic ecology and the use of shelters and latrines by the Neotropical otter (Lontra longicaudis) in the Taquari Valley, Rio Grande do Sul, Brazil. Iheringia. Ser Zool 98: 469-474.

Kasper CB, Feldens MJ, SAlvi J AND Grilho HCZ. 2004a. Estudo Preliminar da ecologia de Lontra longicaudis (Olfers) (Carnivora, Mustelidae) no Vale do Taquari, Sul do Brasil. Rev Bras Zool 21: 65-72.

Kasper CB, SAlvi J AND Grilho HCZ. 2004b. Estimativa do tamanho de duas espécies de ciclídeos (Osteichthyes, Perciformes) predados por Lontra longicaudis (Olfers) (Carnivora, Mustelidae), através de análise das escamas. Rev Bras Zool 21: 499-503.

KoRSCHGEN LJ. 1987. Procedimentos para el análisis de los hábitos alimentarios. In: MOSBY H ET AL. (Eds), Manual de técnicas de géstion de vida Silvestre, Maryland: The Wildlife Society, Maryland, USA, p. 119-134.

Krebs CJ. 1999. Ecological Methodology, $2^{\text {nd }}$ ed., Menlo Park: Benjamin/Cummings, $580 \mathrm{p}$.

KRUUK H. 1995. Wild otter: predation and population, $1^{\text {st }}$ ed., Oxford: Oxford University Press, 290 p.

KRUUK H. 2006. Otters: ecology, behaviour and conservation, $1^{\text {st }}$ ed., Oxford: Oxford University Press, 264 p.

LARIVIÈRE S. 1999. Lontra longicaudis. Mamm Species 609: 1-5.

LEGENDRE P AND LEGENDRE L. 1998. Numerical ecology, $2^{\text {nd }}$ ed., Amsterdam: Elsevier, 853 p.
LEVINS R. 1968. Evolution in changing environments: some theoretical explorations, $1^{\text {st }}$ ed., Princeton: Princeton University Press, $120 \mathrm{p}$.

Louzada-Silva D, Viera TM, Carvalho JP, Hercos AP AND SouZA BM. 2003. Uso de espaço e de alimento por Lontra longicaudis no Lago Paranoá, Brasília, DF. Ciências da Saúde 1: 305-316.

MACÍAS-SÁNCHEZ S AND ARANDA M. 1999. Analisis de la alimentacion de la nutria Lontra longicaudis (Mammalia: Carnivora) en un sector del rio Los Pescados, Veracruz, Mexico. Acta Zool Mex 76: 49-57.

MASON CF AND MACDONALD SM. 1986. Otters: ecology and conservation, $1^{\text {st }}$ ed., Cambridge: Cambridge University Press, $235 \mathrm{p}$.

Monroy-Vilchis O AND Mundo V. 2009. Nicho trófico de La nutria netropical (Lontra longicaudis) em um ambiente modificado, Temascaltepec, México. Rev Mex Biodivers 80: 801-806.

PARDINI R. 1998. Feeding ecology of the neotropical river otter Lontra longicaudis in Atlantic Forest strem, south-eastern Brazil. J Zool (Lond) 245: 385-391.

PARERA A. 1993. The neotropical river otter Lutra longicaudis in Iberá lagoon, Argentina. IUCN Otter Spec Group Bull 8: $13-16$

PILLAR VD. 2006. MULTIV: Multivariate Exploratory Analysis: Randomization Testing and Bootstrap Resampling (Versão 2.4). Universidade Federal do Rio Grande do Sul, Departamento de Ecologia, Brazil.

PILlAR VD AND ORLÓCI L. 1996. On randomization testing in vegetation science: multifactor comparisons of relevé groups. J Veg Sci 7: 585-592.

Quadros J And MonteIro-FILho ELA. 2001. Diet of the Neotropical Otter, Lontra longicaudis, in an Atlantic Forest Area, Santa Catarina State, Southern Brazil. Stud Neotrop Fauna Environ 36: 15-21.

SpínOla RM AND VAUghan C. 1995. Dieta de la nutria neotropical (Lutra longicaudis) en la Estación Biológica La Selva, Costa Rica. Vida Silv Neotrop 4: 125-132.

WAECHTER JL. 1985. Aspectos ecológicos da vegetação de restinga no Rio Grande do Sul, Brasil. Comm Mus Ci PUCRS Sér Bot 33: 49-68. 